Милан Д. Ђурић

Рачунарски факултет у Београду

Универзитет УНИОН
УДК 316.77:004.55

ДОИ https://doi.org/10.18485/

melissa.2016.15.2.ch18

\title{
НИКОЛА ТЕСЛА - ДЕЧАКОВА ПРИЧА У ВИРТУЕЛНОМ ПРОСТОРУ
}

\section{Сажетак}

У архивама Музеја Николе Тесле у Београду налазе се документована Теслина писма о животу, раду и патентима. Једно међу њима је његово писмо у коме препричава своје детињство. Ово писмо је уназад више пута презентовано кроз илустроване књиге и сликовнице. Данас у време дигиталних уметности реализује се и мутимедијални рад путем рачунарске анимације, што је ће у овом раду бити описано.

Писмо Тесле о његовом детињству презентовано је у виртуелном простору путем неколико повезаних холограма који чине једну целину. Одрастање дечака и његова сећања представљена су путем дводимензионалне анимације. Делови приче који се презентују линеарно у временским интервалима на одређеним позицијама у простору чине целине приче и тиме стварају виртуелни простор у раду. Анимиране секвенце изведене су на основу изабраних документованих текстова. Дело садржи и аудио фајл који садржи нарацију тих текстова на српском и енглеском језику, а истовремено прати анимиране холограме.

Различита аниматорска остварења презентована су на изложби поводом стошездесетогог рођендана обележеног у Музеју Николе Тесле у Београду, у оквиру које је аутор рада представио и свој уметнички пројекат, под насловом Никола Тесла - Дечакова прича у виртуелном простору. У овом раду се описује и објашњава настајање изведеног уметничког простора и осветљава виртуелни простор који он представља у делу.

Кључне речи: дигитална уметност, Никола Тесла, виртуелни простор, рачунарска анимација, анимирани холограми, дигитализација, нарација текстова, Музеј Николе Тесле у Београду.

\section{0. Уводна разматрања о Тесли}

Никола Тесла, српско-амерички научник, инжењер и проналазач, рођен је 10. јула 1856. године у селу Смиљану, у Лици. Село Смиљан, недалеко од Госпића (данас у Републици Хрватској), нала- 
зило се тада у Војној граници, у Лици чешће називаној Војна крајина, посебној области Аустријског царства (тј. Хабзбуршке монархије) под царем Францом Јозефом I.

Рођен је као четврто дете у српској породици православног свештеника Милутина Тесле и његове жене Ђуке, рођене Мандић. Његови родитељи имали су сина Данета, који је погинуо када је Никола имао пет година, и три ћерке, Ангелину и Милку, две сестре старије од Николе, и ћерку Марицу, најмлађе дете у породици.

Николина родна кућа налазила се у непосредној близини Цркве Светих Апостола Петра и Павла, у којој је његов отац Милутин служио као прота. У овој цркви крштен је већ 11. јула, и поред обичаја у Лици да се то најраније учини петнаест дана по рођењу. Највероватније да је разлог за ову брзину био родитељски страх од смрти слабашног детета. Име је добио по имену својих дедова и по мајци и по оцу.

Никола Тесла пошао је у основну школу у Смиљану 1862. године. Потом се породица пресељава у Госпић где Никола похађа преостала три разреда основне школе и Нижу реалну гимназију. У Раковцу, крај Карловца, Никола иде у Велику реалну гимназију, у то време познату и цењену школу у којој су се ђаци припремали за студије технике. Матурирао је 24. јула 1873. године. На студије креће 1875. године. Уписује Политехнику „Јоанеум“ у Грацу, која је била једна од четири школе у Аустроугарској које су школовале инжењере. Због изостанка стипендије, 1878. године напушта Грац. Одлази у Марибор и тамо проналази свој први посао инжењера.

Године 1880. одлази у Праг, да према очевој жељи настави студије. На Карловом универзитету започиње студије филозофије, но убрзо их напушта. У Будимпешту се сели 1881. године и запошљава у телеграфској компанији као главни телефонски техничар. У јесен 1882. одлази у Париз и запошљава се у Едисоновој Континенталној компанији на пословима унапређења електричне опреме. У јесен 1883. године послат је у Стразбур да тамо ради на унапређењу рада електричне централе. У Стразбуру борави до пролећа 1884. године. После тога наступа период живота који проводи у Сједињеним Америчким Државама.

Пошто је мој пројекат произилази из тековина дигиталне уметности, а обухвата виртуелни простор и 2Д и ЗД холограмске пројекције, неопходно је да се осврнемо и на холограме и пројекције холограма у виртуелном простору у оквиру дигиталне уметности. 


\section{0. Холограми, виртуелни простор и дигитална уметност}

Виртуелни простор и виртуелни светови у овом раду се дефинишу у смислу који им даје Лев Манович у свом крунском раду Софртвер преузима команду (Manovich 2013), а који чак уводи и концепт виртуелне кинематогрфије. На даље, полазим од одређења на која указује Бодријар (фран. Baudrillard) говорећи о стратегијама „стварног“. Наиме, он истиче да „у исту категорију с немогућношћу да се пронађе неки апсолутни ниво спада и немогућност да се произведе илузија. Илузија више није могућа зато што више није могуће стварно“ (Brodrijar 1991: 23). Међутим, Бодријар, у једном другом свом раду, помиње виртуелност значења, осврнувши се на однос знака у оквиру једначине ово = ово, каже да то не значи ништа друго, а истиче да је та „притајеност стога само начело рационалности знака“ који делује као универзални апстрактор и редуктор свих виртуелности значења која не произилазе из неког одговарајућег оквира, из „истоветности и посебности“ (Baudrillard 2001: 10).

Дакле, у овом раду, узимам једно прилично широко одређење које налазим код Мановича и Бодријара, а које користим као теоријску полазну тачку за даље елаборације и практична остварења мог уметничког пројекта. У наредном делу, погледаћемо укратко концепт холограма, и пројекцију холограма у контексту дигиталне уметности.

\section{1. Холограм и пројекција холограма у дигиталној уметности}

У литератури се наводи да је холографију изумео Денис Габор (енг. Dennis Gabor) 1948. године, као методу за снимање и реконструисање амплитуде и фазе таласног поља, сковавши реч holography (тј. холографија) од грчких речи holos (цео или челокупан) и grafeun (писати) (Schnars and Jueptner 2005: 1). На садашњем ступњу развоја, холограми се обично снимају помоћу оптичког сета, који се састоји од извора светлости (ласера), огледала и сочива за навођење зрака, као и уређаја за снимање, односно, фотографске плоче (Schnars and Jueptner 2005: 21). Ради илустрације, погледаћемо како то изгледа на сликама преузетим из релевантне литературе ${ }^{1}$.

1 На даље, све слике које наводим о холограмима преузете су из извора Schnars and Jueptner 2005: 22. 


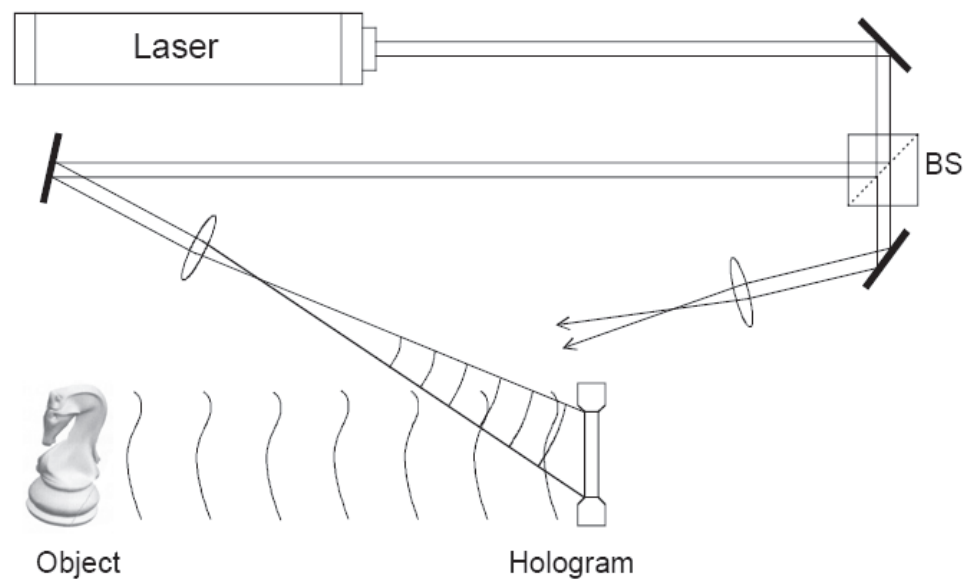

Слика 1.1.1. Снимање холограма.

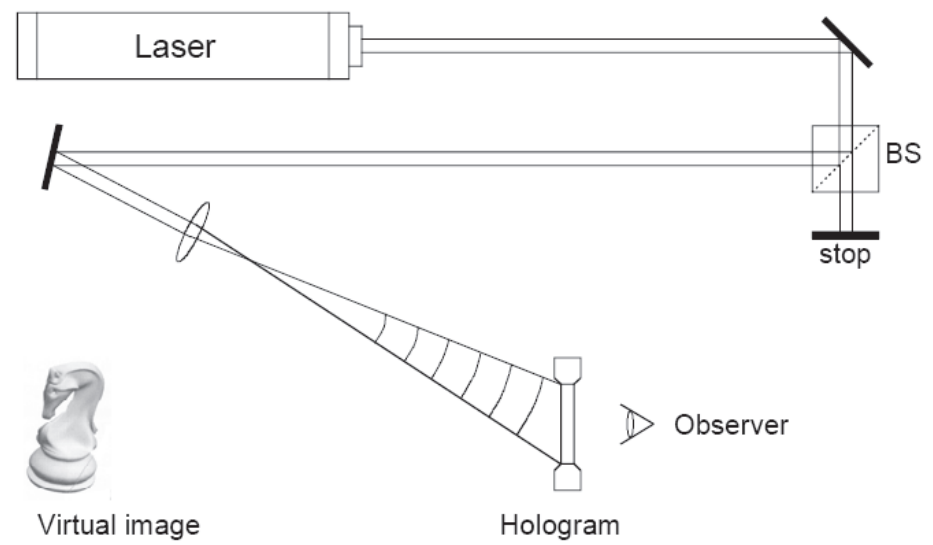

Слика 1.1.2. Реконструкција холограма.

У литератури је могуће уочити да се термин „холограм“ може односити како на енкодирани материјал, тако и на резултујућу слику. Холографска слика се може видети гледањем у осветљену холограмску штампу или пропуштањем ласера кроз холограм и пројектовање те слике на екран.

Друге методе пројектовања слика често се називају „холографским“, зато што су оптички присутне, а имају просторни квалитет. 


\section{Reference wave}

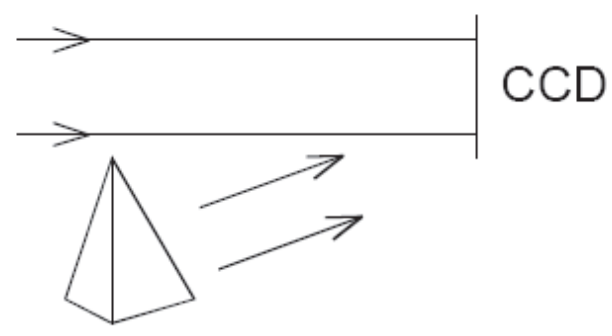

\section{Object}

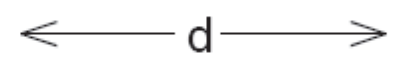

Слика 1.1.3. Дигитална холографија: снимање.

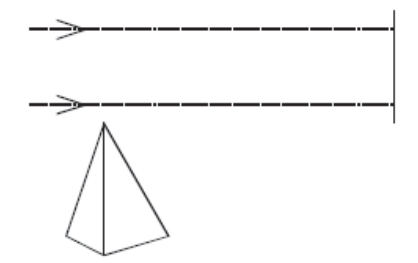

Virtual image

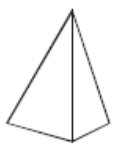

Real image

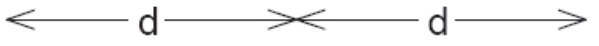

Слика 1.1.4. Дигитална холографија: Реконструкција са референтним таласом $E_{R}$.

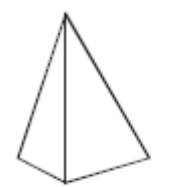

Real image

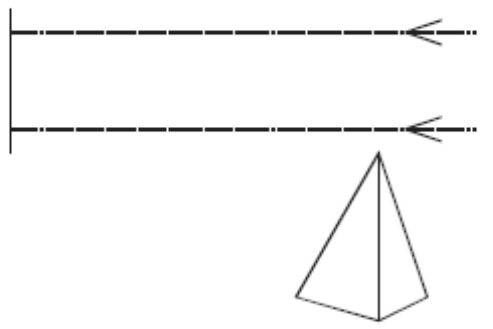

Virtual image

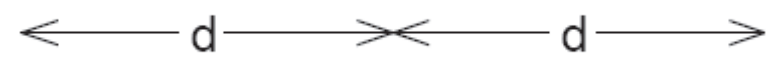

Слика 1.1.5. Дигитална холографија:

Реконструкција са измењеним референтним таласом $E_{R}$. 
Холограм се обично снима на фотографској плочи или на равном делу филма, али производи тродимензионалну (3D) слику. Поред тога, генерисање холограма не подразумева снимање слике у конвенционалном смислу. Како би се разрешили ови очигледни парадокси, а да би се схватило како холографија функционише, потребно је укратко објаснити основне принципе. Наиме, код конвенционалних техника стварања слике, као што је то фотографија, оно што се забележи, тј. снима, јесте само интензитет дистрибуције са оригиналне слике (Hariharan 2002: 1). Као резултат, све информације о оптичким путањама ка различитим деловима те сцене се губе. Јединствена карактеристика холографије јесте идеја снимања како фазе, тако и амплитуде светлосних таласа са објекта. Пошто сви материјали који се снимају реагују само на интензитет на слици, неопходно је конвертовати информацију фазе у варијације интензитета (Hariharan 2002: 1). Холографија то чини употребом кохерентног осветљавања и увођењем референтног светлосног зрака који се добија из истог извора. Фотографски филм бележи тај образац интерференције који производи овај референтни зрак и светлосне таласе које расејава објекат.

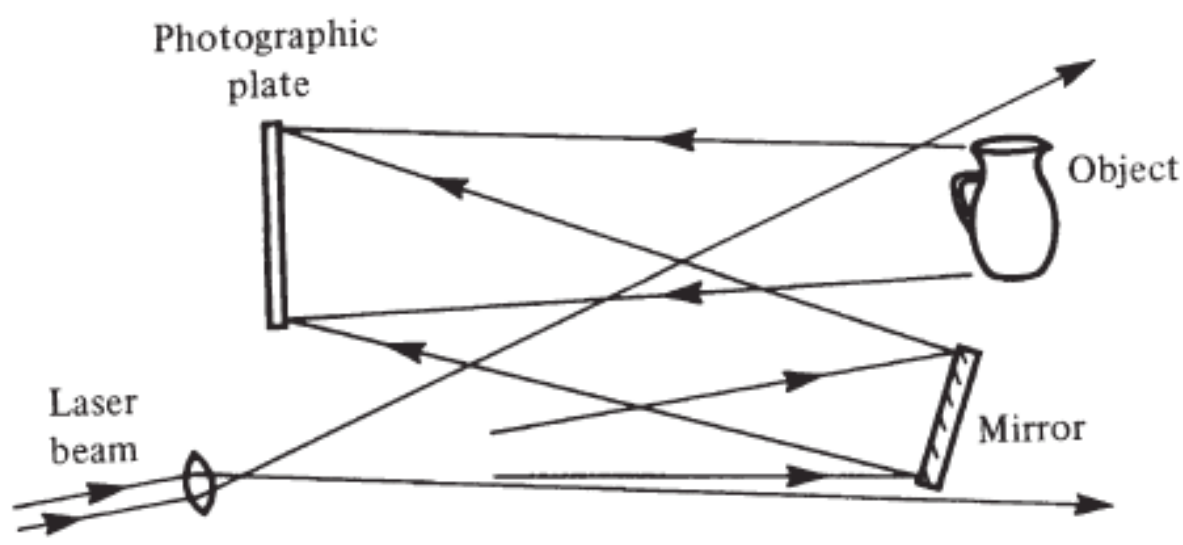

Слика 1.1.6. Снимање холограма: образац интерференције произведен референтним таласом и објектом који се снима. 


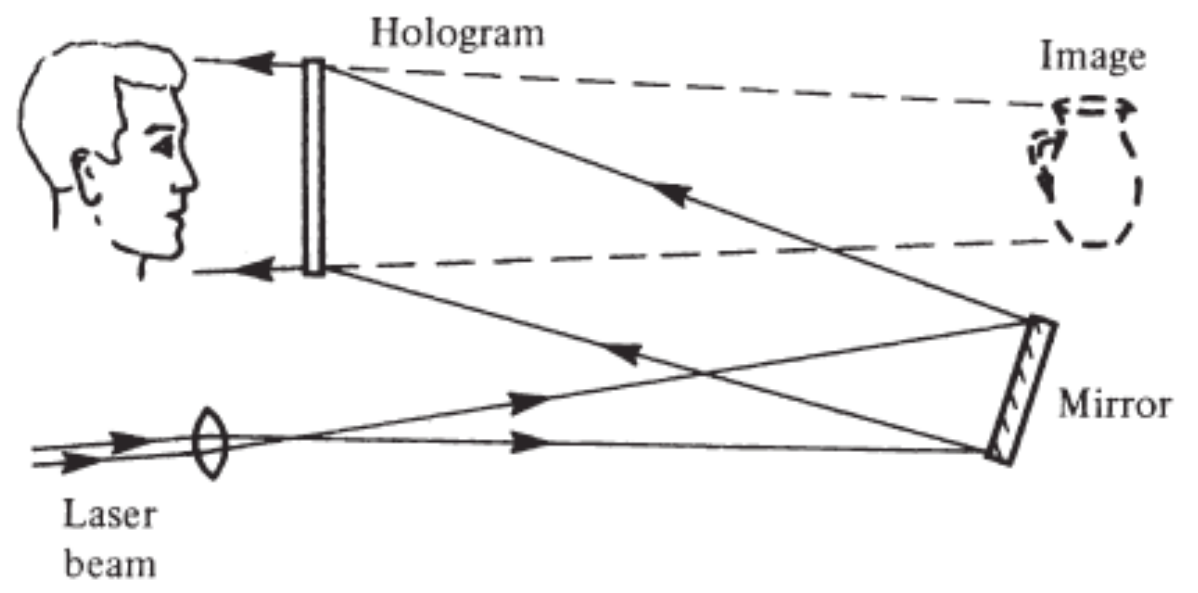

Слика 1.1.7. Реконструкција слике: светло измењено дифракцијом холограмом реконструише талас објекта.

\section{2. Методе презентације 2Д анимације при симулацији ЗД холограма}

Методе које сам применио приликом креирања и реализације дигиталне симулације холограма путем 2Д анимације о Тесли поделио сам у пет сегмената:

1. Одређивање циљева, принципа саопштавања и структуре анимиране дигиталне пројекције о Николи Тесли;

2. Архитектура информација добијених у облику „учитане“ приче;

3. Категоризација добијених информација;

4. Хијерархија установљеног и добијеног дигиталног садржаја;

5. Разрада конкретног концепта 2Д анимације за симулацију ЗД холограма и њена израда.

Током прикупљања информација, занимао ме је однос виртуелне реалности као и однос према телу, погледу и гледаоцима, односно публици. Пошао сам од констатације да смо у виртуелном свету заправо сведоци контекстуализације симбиозе високе технологије и човековог тела, што је генерисало услове за невероватно побољшање друштвене стварности (Gržinić 1998: 108). Радећи на 
уметничком пројекту морао сам да истражим и телеприсуство (енг. telepresence), које је једним својим делом, свакако повезано са дигиталним технологијама. Управо ми је неопходан елемент било телеприсуство, којим остварујем присуство на различитим локацијама у исто време (Paul 2008: 154), што је било релевантно, али и неоходно, приликом рада на пројекту Никола Тесла - Дечакова прича у виртуелном простору.

За архитектуру информација уметничког пројекта Никола Тесла - Дечакова прича у виртуелном простору посебно су корисни и значајни били и дискурси унутар препознатљивих система значења (Gržinić 1998: 108). У том смислу, повезани су анимација Тесле као дечака и процес протока информација. Прецизније, моја анимација Тесле и мачке може се третирати као продужетак или екстензија тела и екстензија реалности, односно, може бити својеврсни remote control, тј. даљински управљач, који нам омогућава да „микопроцесором и хардвером у величини новчаника изгубимо материјалност властитог тијела и одједном се, само једним притиском на дугме, прикључимо на високотехнолошки апарат“" (Gržinić 1998: 108).

Мој задатак презентације дигиталне симулације ЗД холограма путем 2Д анимације који сам користио у пројекту Никола Тесла - Дечакова прича у виртуелном простору условљен је, свакако, предзнањем везаним за вишегодишње бављење анимацијом и проучавањем дигиталне симулације ЗД холограма путем 2Д анимације, у контексту дигиталне манипулације слике на филму, али и у другим областима. Неки од већ постојећих радова и техника утицале су на одабир карактеристика за нове креације. У неколико протеклих година урадио сам више краћих 2Д анимација, карактеристичних по доминацији линије, па сам се при изради дигиталне симулације холограма одлучио за овај приступ. Поред тога, једна од видео реклама, које сам реализовао, садржала је ефекат који сам у изворном облику прихватио, а касније модификовао приликом визуелне презентације карактеристика дигиталне симулације 3Д холограма путем 2Д анимације, као што су боја, интензитет исијавања, али и друге детаље материјализације. 

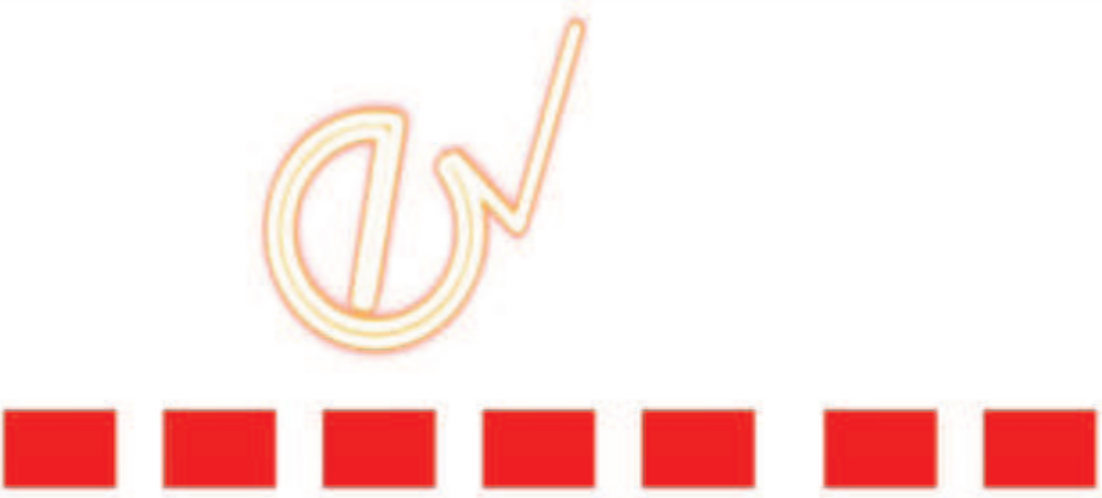

Слика 1.2.1. Видео реклама E-shop-a. (С Милан Ђурић)

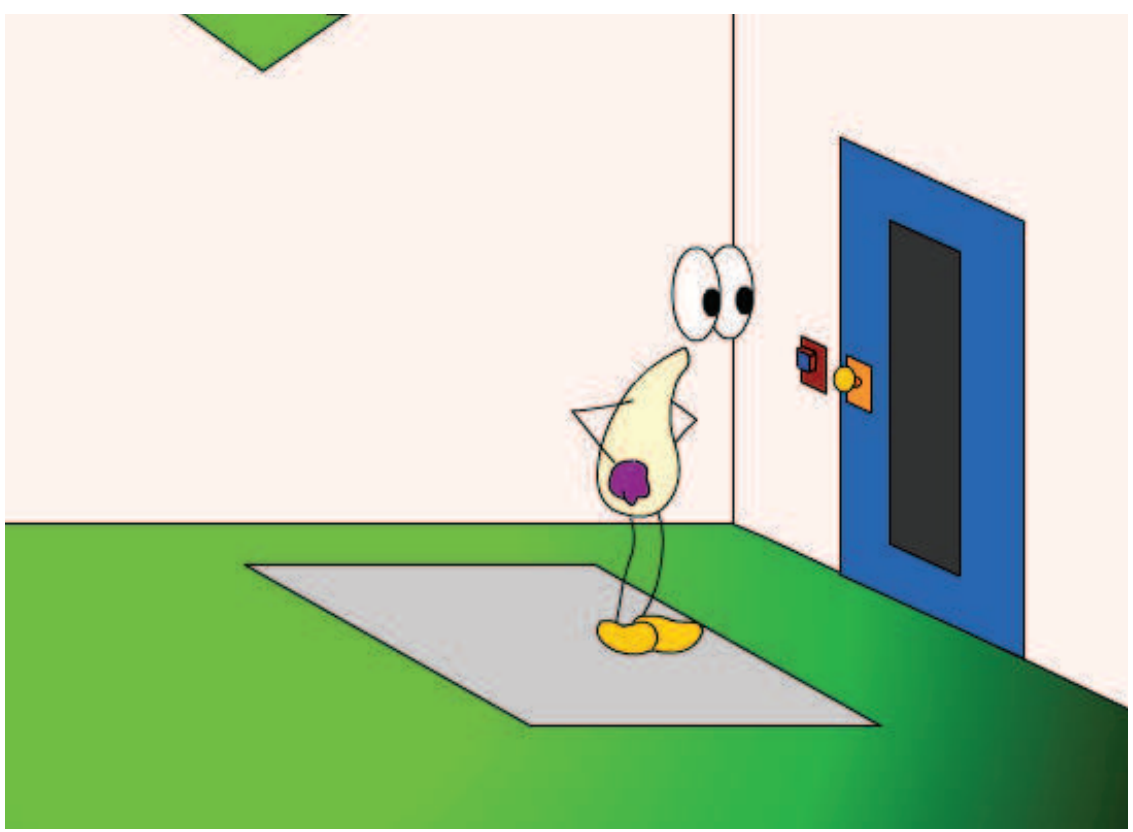

Слика 1.2.2. Детаљ из анимираног филма Blob. (С Милан Ђурић) 


\section{0. Опис пројекта}

2Д дигитално анимирана пројекција холограма у тродимензионалном простору „Никола Тесла - Прича о детињству“ настала је у сарадњи више уметника-аниматора. Ово дело је изведено поставивши анимацију изведену кроз технику ротоскопије у склоп са предефинисано постављеним огледалима на које се анимација презентује и посматрачу одаје утисак холограмске пројекције. Вишеслојну анимацију као целину чине фрагменти састављени од дела сваког аутора понаособ ${ }^{2}$, а свака представља презентацију појмова и ситуација из текста аутентичног писма Николе Тесле које је сачувано у архивама музеја.

Анимирана пројекција постављена је као вишеслојна 2Д анимација у временским интервалима на одређеним позицијама у простору. Холограмска пројекција је смештена у посебно конструисано кућиште тако чинећи дигиталну платформу. Конструисано кућиште је мешавина материјала попут дрвета и стакла која су постављена у јасно дефинисаном положају. Оно садржи део одређених димензија, предвиђен за презентацију анимације која чини анимирану пројекцију холограма, а постављен је директно испред посматрача фронтално, на горњој половини платформе. На страницама ове конструкције налази се препознатљива слика Николе Тесле која сугерише садржај платформе, која је постављена у оквиру изложбе поводом 160 година од рођења Николе Тесле у музеју Николе Тесле у Београду, као део сталне поставке у оквиру дигиталног и интерактивног садржаја. Оваква конструкција платформе заправо чини једну „виртуелну позорницу“ у који можемо испунити како комерцијалним тако и културним или некаквим другим виртуелним садржајем.

2 Уметници-аниматори су: Милан Ђурић, Бојан Стеванић, Ненад Стојановић, Санела Беговић. 
KONSTRUKCIJA PLATFORME ANIMIRANE HOLOGRAMSKE PROJEKCIJE

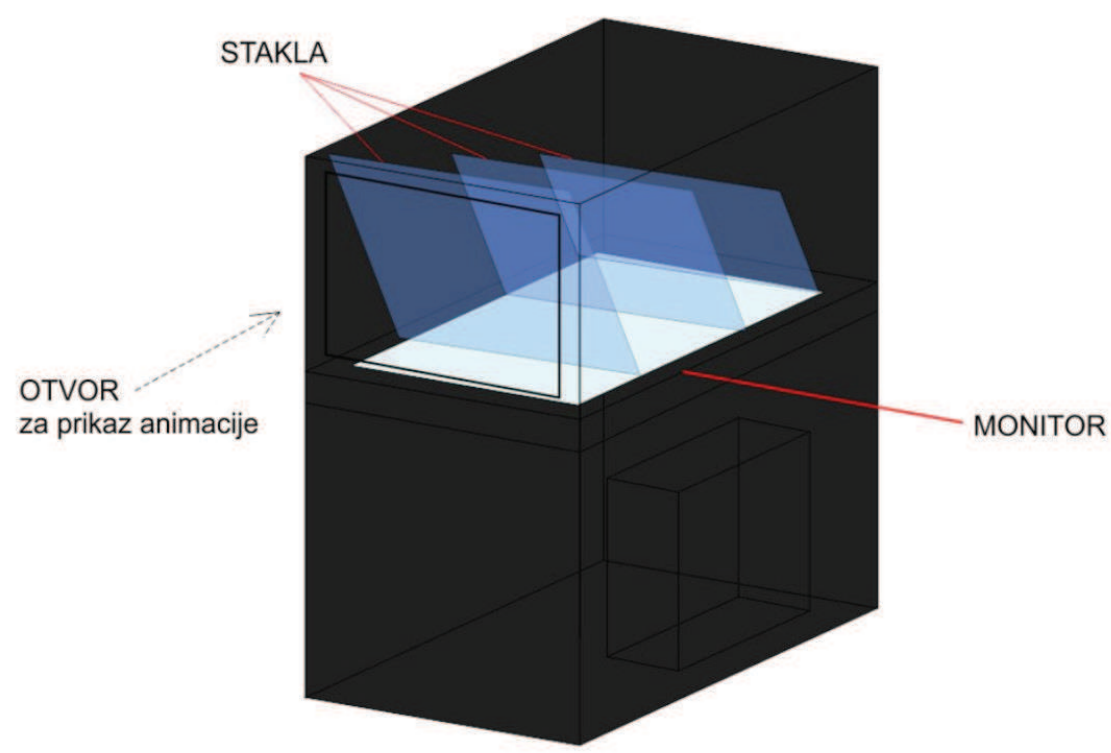

Слика 2.0.1. Конструкција платформе анимиране холограмске пројекције.

Анимирани сегменти су презентација стилизованих форми предмета и људи који су у константој интеракцији са аудио записом. Појмови који се приказују су директно везани за описе из писма Николе Тесле, па се поред места попут планине, села, гробља, појављују и људске фигуре попут брата, мајке као и животиња од којих је незаобилазна и најзначајнија његов мачак, кога у писму детаљно описује дајући му посебан карактер, стога је мачора требало тако и анимирати, на специфичан начин. Све сцене ових стилизација су појединачно анимиране али у платформи повезане у линеарној пројекцији са пратећим аудио записом наратора који чита текст ${ }^{3}$.

Сцене виртуелно комуницирају међусобно јер се њихов садржај сажима у односу на који су постављене. Заправо пројекција холограма је састављена из неколико сегмената који чине једну целину тро- 
димензионалног простора презентованог посматрачу. Сцене садрже више планова који формирају целину виртуелног простора. Планови су некад међусобно повезани садржајем истоветних предмета или живих бића, а понекад су односи предњег, средњег и задњог плана испуњени различитим елементима који пак у већини случајева чине целину кадра. Овако презентован садржај у виду виртуелног простора, подржан звучним записом који га употпуњује, комуницира и са посматрачем пружајући му један аутентичан доживљај оживљавања текста писма Николе Тесле.
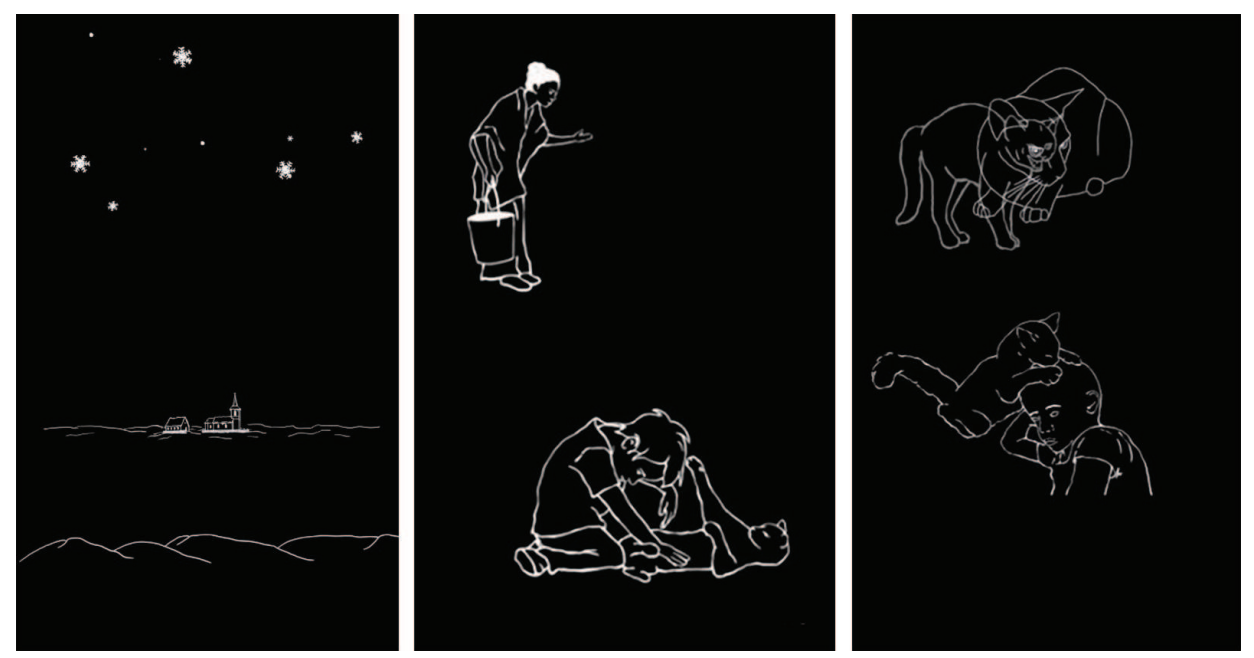

Слика 2.0.2. Фрагменти 2Д анимације са платформе.

Посматрач и конструисана платформа су постављени у простор музеја, а посетиоци су имали прилику да остваре интеракцију, тако што су по слободном нахођењу могли или да посматрају анимацију као независну целину или да стављајући слушалице и преслушавајући тонски запис док посматрају анимацију добију увиду у уметничку целину. Овде је битно било присуство посматрача који на овај начин индиректно учествују у пројекту. Тиме виртуелни простор задобија статус културолошког феномена који обухвата виртуелни простор, дигиталну уметност и анимацију као нешто што повезује све то. 


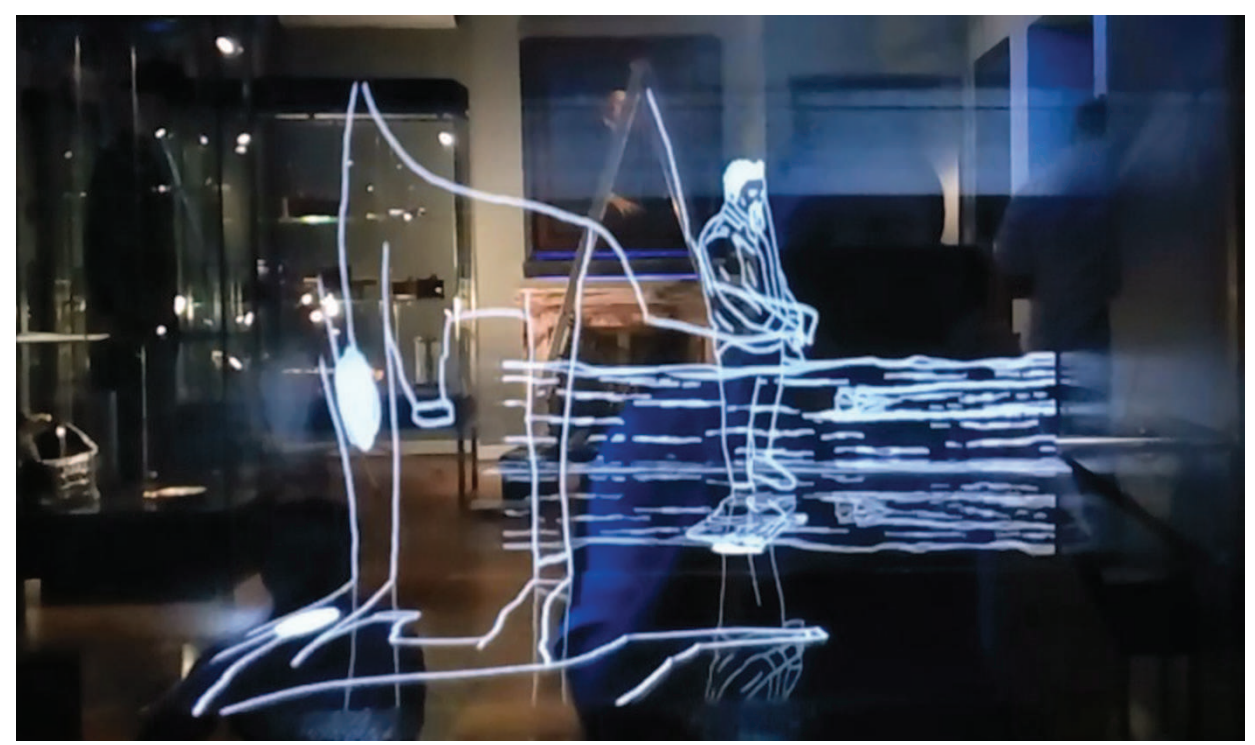

Слика 2.0.3. Дигитална симулација ЗД холограма путем 2Д.

Аудио фајл који је саставни део ове дигиталне платформе није нимало занемарљив, штавише он је смерница без које дигитална пројекција анимације холограма неби имала смисла, што опет не значи да не може егзистирати као засебно уметничко дело, самостално, чинећи виртуелни простор. Аудио запис садржи забележену нарацију текста писма изведену вишејезично, али репродуковано у посебним интервалима. Наратори су посебним техникама дочарали доживљај који је гледањем видео садржаја постајао потпун. Тон је репродукован путем слушалица како би доживљај посматрача био аутентичан. Тонски запис је урађен у посебном студију за снимање тона где је и додатно обрађен. Поред текста урађене су и допуне у виду ефеката попут „фрктања“ мачора који је описиван у тексту а испраћен одговарајућом анимацијом.

На овај начин, обједињавањем аудио записа и анимације добијена је целина која је у музеју сачињавала неопходни део мозаика целокупног пројекта. 


\section{0. Закључне напомене}

У фокусу аутора рада нашло се писмо Николе Тесле о његовом детињству које је кроз уметнички пројекат презентовано у виртуелном простору путем неколико повезаних холограма који чине једну целину. Аутор је настојао да прикаже одрастање дечака и његова сећања добијена на основу ексцерпирања аутентичног писма Николе Тесле добијеног од Музеја Николе Тесле. Ове реминисценције, аутор је представио путем дводимензионалне анимације у тродимензионалном простору. Прецизније, аутор је линеарно комбиновао 2Д анимацију пројектовану у тродимензионалном простору како би реализовао пројекат.

У оквиру пројекта, прикупљени су, обрађени и представљени делови приче који су презентовани линеарно у временским интервалима на одређеним позицијама у простору. Овако конципирани, делови приче су сачињавали целину приче на тај начин креирајући виртуелни простор у уметничком пројекту. У раду је описан пројекат који је садржао анимиране секвенце, које су изведене на основу изабраних и обрађених документованих текстова. Поред тога, у раду је описан и аудио фајл који садржи нарацију одабраних и обрађених текстова на материјалу два језика: српском и енглеском језику. Ови текстови прате анимиране холограме, па се сагледавају као један важан састојак целине пројекта.

Аутор је кроз различита аниматорска остварења добио идеју и реализовао уметнички пројекат, под насловом Никола Тесла - Дечакова прича у виртуелном простору, који је постављен у конкретном уметничком простору. Пројекат осветљава и виртуелни простор који је представљен кроз овај уметнички пројекат. Аутор је увидео и значај телеприсуства и разноврсних феномена који су инструментални у оквиру савремене дигиталне уметности.

\section{Литература}

Baudrillard, Jean. Simulacija i zbilja. Zagreb: Naklada Jesenski i Turk i Hrvatsko sociološko društvo, 2001. Print.

Bodrijar, Žan. Simulakrumi i simulacija. Prevod s francuskog: Frida Filipović. Novi Sad: IP Svetovi, 1991. Print. 
Gržinić, Marina. U redu za virtualni kruh. Zagreb: Meandar, 1998. Print.

Hariharan, Parameswaran. Basics of Holography. Cambridge: Cambridge University Press, 2002. Print.

Manovich, Lev. Software Takes Command. New York: Bloomsbury, 2013. Print.

Paul, Christiane. Digital Art. Revised and Expanded Edition. New York: Thames and Hudson, 2008. Print.

Schnars, Ulf and Werner Jueptner. Digital Holography: Digital Hologram Recording, Numerical Reconstruction and Related Techniques. Berlin and Heidelberg: Springer Verlag, 2005. Print.

Šuvaković, Miško. Pojmovnik suvremene umjetnosti. Zagreb i Ghent: Horetzky i Vlees \& Beton, 2005. Print.

Toffoletti, Kim. Baudrillard Reframed. London: I. B. Tauris \& Co. Ltd., 2011. Print.

Milan D. Đurić

University Union in Belgrade

The Faculty of Computer Science

\section{NIKOLA TESLA - A BOY'S STORY IN VIRTUAL SPACE}

\section{Summary}

Nikola Tesla's letters about life, work and patents can be found documented in the archives of the Nikola Tesla Museum in Belgrade. One of these letters is the one in which he retells his childhood. This letter has been presented so far in illustrated books and picture books. Nowadays, in the era of digital art, multimedia work is carried out by means of computer animation.

The letter of Nikola Tesla is presented in virtual space by means of several interconnected holograms that constitute one whole. The growing up of the boy and his recollection are represented through two-dimensional animation. The parts of the story presenting in a linear manner in time intervals at certain spatial positions constitute the entire story thereby creating virtual space in the work. Animated sequences have been carried out on the basis of the selected documented texts. The work also contains an audio file comprising narration of these texts in Serbian and English, and which simultaneously accompanies the animated holograms.

This work of several animators, one of whom is the author of this text, was presented on the occasion of the $160^{\text {th }}$ birthday marked in the Nikola Tesla Museum in Belgrade. 
The author of the work Nikola Tesla - A Boy's Story in Virtual Space presents the launched art project, explains its origin, and the virtual space it presents in the work itself.

Key Words: Digital Art, Nikola Tesla, Virtual Space, Computer Animation, Animated Holograms, Digitalisation, Text Narration, The Nikola Tesla Museum in Belgrade 